\title{
Uji Daya Hambat Air Perasan Buah Jeruk Nipis (Citrus aurantifolia s.) Terhadap Pertumbuhan Bakteri Staphylococcus Aureus Secara In Vitro
}

\author{
Abdul Razak ${ }^{1}$, Aziz Djamal ${ }^{2}$, Gusti Revilla ${ }^{3}$
}

\begin{abstract}
Abstrak
Jeruk Nipis (Citrus aurantifolia S.) merupakan salah satu tanaman obat keluarga yang banyak terdapat ditengah masyarkat dan banyak digunakan sebagai ramuan tradisional. Bagian yang sering digunakan adalah air perasannya, dengan salah satu manfaat dapat digunakan untuk menghilangkan jerawat serta penyembuhan luka agar tidak terjadi abses. Jerawat dan abses pada luka merupakan salah satu infeksi yang disebabkan oleh bakteri Staphylococcus aureus.

Tujuan Penelitian ini adalah untuk mengetahui daya hambat air perasan buah jeruk nipis (Citrus aurantifolia S.) terhadap pertumbuhan bakteri Staphylococcus aureus secara invitro. Penelitian dilakukan dengan metoda eksperimental laboratorium dengan desain postest only control group design yang dilakukan di Laboratorium Mikrobiologi Fakultas Kedokteran Universitas Andalas.

Hasil penelitian menunjukan bahwa air perasan buah jeruk nipis memiliki daya hambat terhadap pertumbuhan bakteri Staphylococcus aureus dengan berbagai konsentrasi yaitu 25\%, 50\%, 75\%, dan 100\% dan terdapat pengaruh lama kontak terhadap pertumbuhan bakteri dimana bakteri tidak tumbuh seteleh kontak 5 menit pertama dan diikuti menit-menit berikutnya dengan air perasan buah jeruk nipis konsentrasi $100 \%$. Jadi, semakin tinggi konsentrasi air perasan buah jeruk nipis dan semakin lama kontak dengan bakteri Staphylococcus aureus maka daya hambatnya semakin baik.
\end{abstract}

Kata kunci: Uji Daya Hambat, Air Perasan Buah Jeruk Nipis, Staphylococcus aureus.

\begin{abstract}
Lime (Citrus aurantifolia S.) is kind of family's herbal medicine, most using in the community is widely used as a traditional herb. The most common used part is the lime fruit squeeze with one of the function is used for removing acne and wound healing to prevent the form of abscess. Pimples and abscesses of the wound is one of the infections caused by the bacterium Staphylococcus aureus.

The purpose of this study was to determine the inhibition of lime fruit (Citrus aurantifolia S.) squeeze towards the growth of the bacteria Staphylococcus aureus in vitro condition. The study was conducted with laboratory experimental methods to the design of control group design postest only performed at the Laboratory of Microbiology Faculty of Medicine, University of Andalas.

The results showed that the lime fruit (Citrus aurantifolia S.) squeeze has the ability to inhibite the bacterial growth of Staphylococcus aureus with various concentrations of $25 \%, 50 \%, 75 \%$, and $100 \%$ and there is the effect of contact time on the growth of bacteria which the bacteria do not grow after contact the first 5 minutes and the next minute followed by lime fruit squeeze with $100 \%$ concentration lime fruit squeeze. Thus, the higher the concentration of lime fruit squeeze and the longer the contact with the bacteria Staphylococcus aureus is the better towards.
\end{abstract}

Keywords:Inhibition test, The Lime Fruit Squeeze, Staphylococcus Aureus.

Affiliasi penulis : ${ }^{1}$ : Mahasiswa FK Unand. ${ }^{2}$ : Bagian Mikrobiologi FK Unand, dan ${ }^{3}$ : Bagian Anatomi FK Unand, Universitas Andalas, Jl, Perintis Kemerdekaan No. 94, Padang Korespondensi : Abdul Razak, Fakultas Kedokteran, Universitas Andalas, Jalan Perintis Kemerdekaan No. 94, Padang

\section{Pendahuluan}

Jeruk nipis (Citrus aurantifolia S.) merupakan salah satu tanaman toga yang di gunakan pada masyarakat, baik untuk bumbu masakan maupun untuk obat-obatan dari bagian perasan air buah jeruk nipisnya. Untuk obat, jeruk nipis digunakan sebagai penambah nafsu makan, penurun panas (antipireutik), diare, menguruskan badan, antiinflamasi, dan antibakteri. ${ }^{(1,2)}$

Efek air perasan buah jeruk nipis sebagai antibakteri dapat menghambat pertumbuhan bakteri Eschericia colli, Streptococcus haemolyticus, dan Staphylococcus aureus. Salah satu bakteri yaitu Staphylococcus aureus, merupakan bakteri jenis gram positif yang diperkirakan $20-75 \%$ ditemukan pada saluran pernapasan atas, muka, tangan, rambut dan vagina. Infeksi bakteri ini dapat menimbulkan penyakit dengan tanda-tanda yang khas, yaitu peradangan, nekrosis, tampak sebagai jerawat, infeksi folikel rambut, dan pembentukan abses. Diantara organ yang sering diserang oleh bakteri Staphylococcus aureus adalah kulit yang mengalami luka dan dapat menyebar ke orang lain yang juga mengalami luka. ${ }^{(2-6)}$

Lesi yang ditimbulkan oleh bakteri Staphylococcus aureus dapat dilihat pada abses lesi ataupun jerawat. Bakteri menginvasi dan berkembang biak dalam folikel rambut yang menyebabkan kematian sel atau nekrosis pada jaringan setempat. Selanjutnya diikuti dengan penumpukan sel radang dalam rongga tersebut. Sehinggga terjadi akumulasi penumpukan pus dalam rongga. Penumpukan pus ini mengakibatkan terjadinya dorongan terhadap jaringan sekitar dan terbentuklah dinding-dinding oleh sel-sel sehat sehingga terbentuklah abses. Bakteri ini juga akan bisa menyebar ke bagian tubuh yang lain lewat pembuluh getah bening dan pembuluh darah, 
sehingga terdapat juga peradangan dari vena dan trombosis. $^{(6,7)}$

Pengobatan akibat infeksi Staphylococcus aureus dapat diberi antibiotik berupa Penisilin G atau derivat penisilin lainnya, namun pada infeksi yang berat diduga sudah ada beberapa yang telah resisten terhadap penisilin. Akibat timbulnya resistensi dari antibiotik, maka saat ini telah dilakukan pengujian efek tanaman obat antaranya jeruk nipis sebagai antibakteri. Hasil penelitian menunjukan bahwa minyak atsiri daun jeruk nipis mempunyai aktivitas hambatan terhadap pertumbuhan Staphyloccus aureus pada kadar 20\%, 40\% dan $80 \%$ serta Escherichia coli pada kadar $40 \%$ dan $80 \% .{ }^{(7,8)}$

Berdasarkan hasil penelitian, minyak atsir pada daun jeruk nipis yang menghambat pertumbuhan bakteri Staphylococcus aureus, juga terdapat pada air perasan buah jeruk nipis. Selain itu juga, dengan mengetahui adanya kebiasaan ditengah masyarakat, mengenai penggunaan air perasan buah jeruk nipis dalam upaya menghilangkan jerawat serta penyembuhan luka agar tidak terjadi abses, dimana salah satu penyebabnya Staphylococcus aureus. Mengetahui adanya efek antibakteri air perasan buah jerk nipis yang telah diuji pada beberapa kuman patogen, maka dari itu penulis tertarik untuk melakukan uji daya hambat buah jeruk nipis terhadap pertumbuhan Staphylococcus aureus secara invitro.

Penelitian ini dilakukan dengan tujuan untuk mengetahui daya hambat air perasan buah jeruk nipis (Citrus aurantifolia S.) terhadap pertumbuhan bakteri Staphylococcus aureus secara in vitro.

\section{Metode}

Penelitian dilakukan di Laboraturium Mikrobiologi Fakultas Kedokteran Universitas Andalas pada bulan Oktober 2011 - September 2012. Penelitian ini bersifat eksperimental dengan desain Postest Only Control Group Design. Variabel adalah air perasan buah jeruk nipis dengan berbagai konsentrasi yaitu 25\%, 50\%, 75\%, dan $100 \%$ dan bakteri Staphylococus aureus. Alat yang digunakan adalah cawan petri, tabung reaksi, kertas saring, pelubang kertas, lem, jarum ose, lampu spiritus, pinset, gelas ukur, otoklaf, inkubator, spuiy dispossible, lidi kapas steril, mistar, pisau, dan talenan. Bahan yang digunakan adalah air perasan buah jeruk nipis, biakan murni Staphylococcus aureus, aquades steril, $\mathrm{NaCl}$ 0,9\%, dan Alkohol 70\%. Data hasil penelitian diolah secara statistik dengan metode Anova satu arah dengan derajat kepercayaan 95\% $(=0,05)$ dan bila didapat perbedaan nyata antar perlakuan maka akan dilanjutkan dengan Post Hoc Test dengan taraf kesalahan $1 \%$.

\section{Hasil dan Pembahasan}

Tabel 1. Hasil Uji daya hambat air perasan buah jeruk nipis (Citrus aurantifolia $\quad$ S.) terhadap pertumbuhan bakteri Staphylococcus aureus

\begin{tabular}{lllll}
\hline \multirow{2}{*}{ Konsentrasi } & $\begin{array}{l}\text { Diameter } \\
(\mathbf{m m})\end{array}$ & bebas & kuman & $\begin{array}{l}\text { Diameter } \\
\text { bebas } \\
\text { kuman } \\
\text { rata-rata }\end{array}$ \\
\cline { 2 - 5 } & I & II & III & \\
\hline $\begin{array}{l}\text { Larutan Kontrol } \\
\text { (Aquades } \\
\text { steril) }\end{array}$ & 0 & 0 & 0 & 0 \\
\hline $\mathbf{2 5 \%}$ & 5 & 5,5 & 5 & 5.167 \\
\hline $\mathbf{5 0 \%}$ & 6,5 & 6,5 & 5,5 & 6,167 \\
\hline $\mathbf{7 5 \%}$ & 8 & 8 & 6,5 & 7,5 \\
\hline $\mathbf{1 0 0 \%}$ & 13,5 & 10 & 8 & 10,5 \\
\hline
\end{tabular}

Dari Tabel 1. didapatkan bahwa pemberian air perasan buah jeruk nipis dengan konsentrasi berbeda memiliki daya hambat yang berbeda pula terhadap pertumbuhan bakteri Staphylococcus aureus. Perbedaan ini selanjutnya diuji dengan pengukuran statistik secara komputerisasi menggunakan program SPSS 15.0 for Windows. Berhubung data hasil penelitian yang didapatkan ternyata tidak memenuhi syarat uji annova satu arah. Untuk melanjutkan pengolahan, data ditranformasi, tetapi ternyata data tidak dapat ditranformasi maka pengolahan data dilanjutkan dengan Kruskall Wallis Test. Hasil dpat dilihat pada Tabel 2.

Tabel 2. Perbandingan data stasitik diameter hambatan air perasan buah jeruk nipis (Citrus aurantifolia S.) terhadap pertumbuhan bakteri Staphylococcus aureus dengan menggunakan MannWhitney Test

\begin{tabular}{|c|c|c|c|c|}
\hline No. & Variabel & Konsentrasi & $\begin{array}{l}\text { Konsentrasi } \\
\text { lainnya }\end{array}$ & $\mathbf{P}$ \\
\hline \multirow{3}{*}{1.} & \multirow{6}{*}{$\begin{array}{l}\text { Konsentrasi } \\
\text { air perasan } \\
\text { buah jeruk } \\
\text { nipis }\end{array}$} & & $50 \%$ & 0,068 \\
\hline & & $25 \%$ & $75 \%$ & 0,043 \\
\hline & & & $100 \%$ & 0,046 \\
\hline \multirow{2}{*}{2.} & & \multirow{2}{*}{$50 \%$} & $75 \%$ & 0,099 \\
\hline & & & $100 \%$ & 0,046 \\
\hline 3. & & $75 \%$ & $100 \%$ & 0,105 \\
\hline \multicolumn{5}{|c|}{$\begin{array}{l}\text { Hasil uji statistik didapatkan nilai } \mathrm{p}=0,022 \\
\text { yang berarti bahwa perbedaan yang } \\
\text { na antara konsentrasi yang diberikan dengan } \\
\text { bebas bakteri yang dihasilkan, sehingga } \\
\text { ahan data dilanjutkan dengan Mann-Whitney } \\
\text { Hasil yang didapatkan adalah terdapat } \\
\text { aan yang bermakna antara pemberian } \\
\text { trasi } 25 \% \text { dengan } 75 \% \text {, } 25 \% \text { dengan } 100 \% \text {, } \\
0 \% \text { dengan } 100 \% \text {. Terlihat bahwa tidak } \\
\text { tnya perbedaan bermakna antara pemberian } \\
\text { trasi } 25 \% \text { dengan } 50 \%, 50 \% \text { dengan } 75 \% \text {, dan } \\
\text { engan } 100 \% \text {, dimana hal tersebut dapat }\end{array}$} \\
\hline
\end{tabular}


antibakteri dan tingkat keasaman yang tidak memiliki perbedaan yang bermakna antara konsentrasi.

Tabel 3. Pengaruh lama kontak dari air perasan buah jeruk nipis (Citrus aurantifolia S.) konsentrai $100 \%$ terhadap pertumbuhan bakteri Staphylococcus aureus

\begin{tabular}{ll}
\hline Lama Kontak & Pertumbuhan Kuman \\
\hline Seketika & + \\
\hline 5 menit & - \\
\hline 10 menit & - \\
\hline 15 menit & - \\
\hline 20 menit & - \\
\hline 25 menit & - \\
\hline 30 menit & - \\
\hline
\end{tabular}

Dari Tabel 3. didapatkan bahwa lama kontak bakteri Staphylococcus aureus dengan air perasan buah jeruk nipis berpengaruh terhadap pertumbuhan kuman. Pada lama kontak seketika masih terdapat pertumbuhan bakteri dan mulai dari lama kontak 5 menit terlihat bakteri tidak tumbuh lagi pada daerah agar Mueller Hinton II.

Setelah dilakukan penelitian, hasil yang didapat menunjukan bahwa air perasan buah jeruk nipis memiliki daya hambat terhadap pertumbuhan bakteri Staphylococcus aureus, hal itu dapat dilihat adanya lingkaran bening bebas pertumbuhan bakteri disekitar cakram setelah dibiarkan dalam waktu 24 jam dengan suhu $37^{\circ} \mathrm{C}$, dan tidak terdapatnya pertumbuhan bakteri Staphylococcus aureus setelah berkontak dengan air perasan buah jeruk nipis pada 5 menit pertama dan diikuti dengan menit berikutnya.

Penelitian uji daya hambat air perasan buah jeruk nipis terhadap pertumbuhan bakteri Staphylococcus aureus menunjukan bahwa air perasan buah jeruk nipis dengan konsenrasi 25\%, $50 \%, \quad 75 \%$, dan $100 \%$ dapat menghambat pertumbuhan bakteri tersebut. Hal ini menunjukkan adanya senyawa aktif antibakteri dalam air perasan buah jeruk nipis yang diduga diperoleh dari kandungan kimia yang terdapat di dalamnya, seperti minyak atsiri, diantaranya fenol yang bersifat sebagai bakterisidal, yang mungkin mampu menghambat pertumbuhan dari bakteri Staphylococcus aureus. ${ }^{(3)}$

Kemampuan bakterisidal dari fenol dengan mendenaturasikan protein dan merusak membran sitoplasma sel. Ketidakstabilan pada dinding sel dan membran sitoplasma bakteri menyebabkan fungsi permeabilitas selektif, fungsi pengangkutan aktif, pengendalian susunan protein sel bakteri terganggu. Gangguan integritas sitoplasma berakibat pada lolosnya makromolekul, dan ion dari sel. Sel bakteri kehilangan bentuknya sehingga lisis. Persenyawaan fenolat bersifat bakteriostatik atau bakterisid tergantung dari konsentrasinya. ${ }^{(9,10)}$

Perbedaan lama kontak air perasan buah jeruk nipis dengan konsentrasi yang sama, ternyata juga memiliki perbedaan efek terhadap pertumbuhan
Staphylococcus aureus, ini dapat dilihat dari pertumbuhan bakteri dimasing-masing lama kontak. Lama kontak 5 menit pertama sudah tidak terdapat pertumbuhan pada daerah agar Mueller Hinton II, ini membuktikan bahwa air perasan buah jeruk nipis memiliki daya antibakteri yang sangat kuat sehingga dalam waktu yang singkat air perasan jeruk nipis dapat menghambat pertumbuhan bakteri secara optimal.

Keasaman pada buah jeruk nipis disebabkan oleh kandungan asam organik berupa asam sitrat dengan konsentrasi yang tinggi juga dapat menjadi salah satu faktor yang dapat menghambat pertumbuhan bakteri tersebut. ${ }^{(11)}$ Pengukuran $\mathrm{pH}$ pada air perasan buah jeruk nipis dilakukan dengan menggunakan $\mathrm{pH}$ meter menunjukan bahwa air perasan buah jeruk nipis dengan konsentrasi 25\%, $50 \%, 75 \%$, dan $100 \%$ memiliki pH masing-masing yaitu 2,332; 2,302; 2,275; dan 2,266. Pengenceran dengan $\mathrm{NaCL}$ 0,9 \% mengakibatkan derajat keasaman semakin berkurang, dimana diameter daerah bebas kuman yang terbentuk semakin kecil. Hal ini menunjukan adanya peranan derajat keasaman terhadap semakin baiknya daya hambat air perasan buah jeruk nipis terhadap pertumbuhan bakteri Staphylococcus aureus.

Penelitian daya hambat minyak atsiri pada daun jeruk nipis juga telah dilakukan oleh Ratih Diah Pertiwi (Fakultas Farmasi UGM, 1992), dimana terdapat aktivitas hambatan terhadap bakteri Staphylococcus aureus, pada konsentrasi $20 \%, 40 \%$, dan $80 \%$.

Berdasarkan hasil penelitian ini maka dapat dinyatakan bahwa hipotesis penelitian diterima, karena terdapat daya hambat air perasan buah jeruk nipis terhadap pertumbuhan bakteri Staphylococcus aureus dimana semakin besar konsentrasi air perasan buah jeruk nipis dan semakin lama kontaknya dengan kuman, maka daya hambat air perasan buah jeruk nipis terhadap bakteri Staphylococcus aureus semakin baik.

\section{Simpulan}

Air Perasan buah jeruk nipis memiliki daya hambat terhadap pertumbuhan dari bakteri Staphylococcus aurfeus pada konsentrasi $25 \%, 50 \%$, $75 \%$, dan $100 \%$ dimana semakin tinggi konsentrasi air perasan buah jeruk nipis maka daya hambat air perasan buah jeruk nipis terhadap pertumbuhan kuman Staphylococcus semakin baik.Terdapat pengaruh lama waktu kontak air perasan buah jeruk nipis terhadap pertumbuhan bakteri Staphylococcus aureus yaitu semakin lama kontak bakteri Staphylococcus aureus dengan air perasan buah jeruk nipis maka daya hambat perasanbuah jeruk nipis terhadap pertumbuhan bakteri Staphylococcus aureus semakin baik, tepatnya air perasan buah jeruk nipis sudah memiliki daya hambat terhadap pertumbuhan bakteri Staphylococcus aureus pada lama waktu 5 menit pertama.

\section{Daftar Pustaka}

1. Haryanto, Sri, 2006 . Sehat dan Bugar Secara Alami. Jakarta: Penebar Plus. hal 60

2. Mursito, Bambang, 2006. Ramuan Tradisional untuk Pelangsing Tubuh. Jakarta: Penebar Swadya.

3. Hariana, Arief, 2006. Tumbuhan Obat \& Khasiatnya seri 1. Jakarta: Penebar Swadya. hal $149-150$ 
4. Arias, Kathleen Meehan, 2010. Investigasi dan Pengendalian Wabah di Fasilitas Pelayanan Kesehatan. Jakarta: EGC.

5. Sasongko, Wisnu, 2008. Armageddon 2 : Antara Petaka dan Rahmat. Jakarta: Gema Insani.

6. Usman-Chatib Warsa, 1993. Kokus Positif Gram. Dalam (Staff Pengajar FKUI) Buku Ajar Mikrobiologi Kedokteran, edisi revisi. Jakarta: Bina Rupa Aksara. hal 103-11.

7. Jawetz, E., et all, 2004. Mikrobiologi. Kedokteran. Jakarta: EGC. hal 211-217

8. Dalimartha, Setiawan, 2000. Atlas Tumbuhan Obat Indonesia. Jakarta: Trubus Agriwidya. Hal 86.

9. Rahayu, P. Winiati. 2000. Aktivitas Antimikroba Bumbu Masakan Tradisional Hasil Olahan Industri Terhadap Bakteri Patogen dan Perusak. Vol 11(2). Buletin Teknologi dan Industri Pangan.

10. Pelczar, J. Michael dan Chan, E. C. S., 1988. Dasar-dasar Mikrobiologi 2. Penerbit UI Press: Jakarta.

11. Astawan, Made dan Andreas Leomitro Kasih, 2008. Khasiat Warna-Warni Makanan. Jakarta: PT. Gramedia Pustaka Utama. Hal 98. 